attempt to write hurriedly invariably brought on an attack such as $I$ have described above, followed by symptoms which clearly pointed to an aggravation of the cardiac mischief, more particularly to an increase of the dilatation of the right cavities.

3. In those who are the subjects of valvular disease there is considerable danger of increasing the cardiac trouble. One case illustrated this in a marked manner. The patient was a young man whom I had previously treated for mitral regurgitation. He had steadily improved, competency was established, and the amount of regurgitation had become comparatively slight. One evening he was called upon to finish a number of documents in a hurry; he suffered, as be was doing them, from his heart in the manner which $I$ have described above and on the next day he felt too ill to go out. On my being called to see him I found him in a half-fainting condition with a scarcely perceptible pulse but with a pronounced apex-beat, a markedly accentuated pulmonary second sound, and other evidences of considerable mitral regurgitation. Such a result occurring suddenly seems explicable only on the hypothesis of an interference with the blood-supply to the myocardium, the condition which $\mathrm{I}$ have described above as temporary malnutrition. It may be argued that the latter is of too short a duration to have any appreciable influence on the muscular tissue of the organ, but it must be remembered (a) that the regurgitation itself would in its turn tend to keep up the diminution in the amount of blood passing through the coronary arteries, and (b) that pathological changes in the left ventricle taking place as the result of anæmia of its substance are apt to occur with surprising rapidity. While I do not wish to infer that the changes in this case were of a permanent nature still it is feasible to suppose that a serious weakening either of the papillary muscles or of the fibres surrounding the mitral orifice had occurred, with the result above described.

4. The dangers of this condition in middle-aged or elderly persons, especially those presenting any signs of atheroma, are too obvious to need more than a mere mention. In such cases it is of the utmost importance to warn the patients against the harm of writing in a hurry. They are not likely to injure themselves by hill-climbing or athletics and they have probably learned by experience that it is better for them not to run upstairs or hurry to catch trains, but it has never dawned upon them that in their daily correspondence they are liable to a form of exertion equally dangerous both in its immediate and its more remote effects.

Penarth, South Wales.

\section{POST-DIPHTHERITIC PALST OF THE OCULAR MUSCLES.}

BY J. PORTER PARKINSON, M.D., M.R.C.P. LOND., PHY IIIAN TO OUT-PATIETTS, NORTH-EASTERN HOSPITAL FOR CHILDREN LATE MEDICAL REGISTRAR TO WESTMINSTER HOSPITAL; AND

SYDNEY STEPHENSON, M.CH., F.R.C.S. EDIN., ') PHYHALMIC SURGEON, YORTH-EASTERN HOSPITAL YOR CHIIDREX, ETC.

From time to time cases have been recorded where palsy of the extrinsic ocular muscles has followed diphtheria. A glance at the scattered literature shows that the condition may involve one or several muscles and that it may or may not be associated with paresis of accommodation. For instance, in the cases of Henoch and of Heinz the external recti suffered; in Rumpf's patient the internal recti were paralysed; and in Kraus's case the superior oblique of one side was affected. The levator palpebra superioris may be attacked either by itself (Callan) or along with other muscles (Benson and Ewetzky). Extensive paralyses amounting to ophthalmoplegia externa have been noted by Donders, Hasche, Uhthoff, and Mendel among other writers. It is scarcely necessary to say that these affections may occur as a sequel to diphtheria of any part of the body. Dr. W. Gayton ${ }^{1}$ recorded a case where diphtheria of the genital organs was succeeded some three weeks later by palatal paralysis and " marked strabirmus."

'The general view that post-diphtheritic paralysis of the extrinsic ocular muscles is infrequent is endorsed by Gowers in his widely-quoted "Manual of Diseases of the Nervous

1 The Lancet, May 26th, 1894.
System" (1888). On page 178 of that invaluable work it is stated tbat " a rare cause of palsy of the external muscles is diphtheria." Despite this expression of opinion from so distinguished an authority our experience leads us to believe that as a matter of fact such cases are not very uncommon, although they may not often be brought for treatment to hospital unless the eye condition is complicated by some more serious and striking form of paralysis. In support of this view we are able to quote two recent cases which have fallen under our notice in consecutive months at the NorthEastern Hospital for Children, Shoreditch.

CASE 1.-A girl, aged nine years, was admitted to the hospital under one of us on April 13th, 1898. Seven weeks prior to coming under notice she was treated at home for what was described as "an ulcerated throat." During the last two or three weeks the mother had noticed that the child experienced difficulty both in swallowing and in breathing and that fluids taken by the mouth were apt to return through the nose. The mother further stated that for the last week the sight had been so bad that the patient "could not read print at all." On admission, the child was found to be anæmic with wellmarked nasal phonation; the soft palate was immobile on phonating, while on being touched no reflex was elicited. There was slight ptosis. The pupils were large and equal; they reacted sluggishly to light and not at all to accommodation. The extrinsic eye muscles were paralysed except the external recti and (possibly) the superior oblique. There was therefore a condition of crossed diplopia. Refraction (estimated by direct ophthalmoscopic examination) wasright eye $2 \mathrm{D}$. and left eye $3 \mathrm{D}$. of hypermetropia. The fundi were normal except for the existence of a congenital crescent (Fuchs) at the lower part of each optic disc. The gait was weak with a tendency to sway and fall ; the kneejerks were absent. The movements of the diaphragm on respiration appeared to be deficient; respiration was markedly thoracic. The heart was normal; the pulse was 100, regular, and compressible. The urine was 1020 , acid, with no sugar or albumin ; there was a slight deposit of phosphates. The patient was kept in bed, placed upon full diet and port wine, and given half a drachm of Waston's syrup thrice daily. She gradually improved. The ptosis disappeared after she had been a week in hospital and by this time the diplopia had lessened and slight movements of the affected eye muscles could be made out. Improvement continued until May 13th when she was discharged on account of infectious disease in the ward. Some five months later (Oct. 19th, 1898) the child was brought to the hospital for examination. The gait was strong; the knee-jerks were present, and the palatal reflex was normal. The pupils were equal and contracted both to light and to accommodation. There was no strabismus and binocular vision was present. Amplitude of accommodation was-right eye $12 \mathrm{D}$. and left eye $13 \mathrm{D}$

CASE 2.-A boy, aged five years, was brought to the hospital on May 18th, 1898, suffering from a strabismus said to have been present for one week only. His mother's story was that at the beginning of April the child developed a sore-throat associated with feverishness and swollen cervical glands. On May 11th she noticed that his left eye turned inwards and further inquiry brought out the fact that the lad had "talked thick" for about five days before the strabismus came on. Upon examination there was a convergence of the left eye measuring on the perimeter $30^{\circ}$, while the so-called secondary deviation of the other eye was $40^{\circ}$ or more. Owing to the tender age of the child the diplopia that was present could not be investigated with any satisfactory result. There was a distinct reduction of the outward morement of the squinting eye. Letters of No. 1 Jaeger could be read. The fundi were normal. The gait was unsteady and there was a tendency to fall when the patient attempted to run or to turn quickly; the knee-jerks were absent. The palate was normal; the voice was not nasal. The pulse was 100 and regular. The urine was free from albumin. The child was thin, white, and looked rather ill. On June 1st ore drachm of Parrish's syrup was ordered three times a day. When seen a week later (June 8th) the strabismus had disappeared but the knee-jerks were still wanting. On June 20 th the latter had returned, although the patient was stated to be still "weak on his legs." He eventually made a complete recovery.

From the foregoing remarks it will be noticed that one of our patients suffered from paresis of the external rectur without affection of accommodation, whereas the otber 
manifested a complete, or almost complete, paralysis of the extra-ocular branches of the third nerve, together with impairment of the function of accommodation. In both cases there existed the signs of a more generalised diphtherial poisoning, as shown by paralysis of the palate and lower extremities, with loss of their reflexes. It is satisfactory that both children made so good a recovery under the simple means adopted.

\section{A CASE OF ACUTE PURPURA HÆMOR- RHAGICA; RECOVERY.}

BY E. RUMLEY DAWSON, L.R.C.P. LOND., M.R.C.S. ENG.

THE patient was a girl, aged two years and eleven months, and was first seen by me at midday on Sept. 6th, 1896. Her family history on both sides was good, there being no record of rheumatism or suspicion of hæmophilia. She had not had any children's complaint whatever, either measles, scarlet fever, or whooping-cough. She was, in fact, a thoroughly healthy girl, but during the last two weeks of August, 1896, she had had toothache on and off and during that time had slight epistaxis-i.e., a few spots only of blood from the nose once or twice a week. During this last week-viz., the first week of September-she seemed to be quite well. On the night of Sept. 4th the toothache returned and lasted during the following day. She had an egg for dinner that day and went to bed at night all right, but her mother noticed that the urine which she passed was of a deep-brown colour. At 2 A.M. on Sept. 6th the child woke wanting to pass urine which was done with pain and crying. The mother then saw that there was a rash about the child and that what she had passed into the utensil was about half a pint of very nearly pure blood. The mother was sure that there was no eruption about the child when put to bed. The child kept dozing after this till 4 A.M. when she dropped off to sleep soundly till 7 A.M. At 9 A.M. epistaxis began and it continued with varying intermissions till the afternoon. At midday on examination I found the child to be well nourished and in clean and healthy surroundings. She passed urine in my presence and $I$ saw that it was a small half-pint of nearly pure blood, coming per urethram. Her temperature was normal and the pulse was 126. 'The child showed abundant spots or petechix, varying in size from a pin's head to a sixpenny-piece, not raised or itching or fading on pressure; in colour they were deep aniline blue, purple, rose-red, and dark-red, and were situated on her left cheek and forehead, the lower part of the abdomen, the hips, and on both legs, with one or two spots on each foot and one on the left forearm. She was given a mixture of citrate of iron and ammonia with syrup. At 2 P.M. hæmatemesis came on and recurred three or four times afterwards. Urine was passed again at 4 P.M., nearly half a pint of blood as before, and was passed with pain, no blood coming from the vagina. Two doses of medicine had been given but as it seemed to induce vomiting, and that was of blood, the medicine was stopped and only ice was given to suck and to swallow. One or two petechiæ were seen on the roof of the mouth. After 4 P.M. epistaxis from both nostrils was continuous. The bowels acted at 7.30 P.M. without bleeding. Oil of turpentine was now added to the previous medicine and was given hourly. At my next visit, at 9.30 P.M., the room looked like a slaughterhouse, everything being; spattered with blood. The child's temperature was normal and her pulse was weaker and still 126. She was very restless, throwing herself about and crying out in pain, especially in the abdomen; she was covered with blood and it was impossible to thoroughly examine her owing to her restlessness, so I was unable to say whether the gums and mouth were bleeding themselves or whether the blood spat out and removed by her fingers came only down from the nose. She wished to pass urine and I helped to set her on the utensil in the bed; this at once induced syncope and, in fact, for some time I thought that she was dead, so that she was laid down again without emptying the bladder. At 11.15 P.M. I saw the child again. There was no more hæmatemesis but her nose was still bleeding. In my presence she passed lying down, about an ounce of pure blood per urethram with pain. She had nothing but ice, brandy-and-ice, and medicine with ice. She was in extremis, almost pulseless, and very blanched.

It now occurred to me to do what I should have done for an adult with severe uterine hxmorrhage-i.e., to give deep injection of ergotin into the buttock, so I gave a 5 minim injection into the left buttock of injectio ergotini hypodermica B.P. The hæmorrhage stopped almost immediately, like turning off a water-tap. Slight epistaxis recurred at 12.30 A.M. on Sept. 7th and lasted for about a quarter of an hour. She slept soundly till 5 A.M. when ste awoke to vomit some " coffee-ground" material. At about 4 A.M., while asleep, she passed a brownish motion without any bright blood into the bed. At $6 \mathrm{~A} . \mathrm{M}$. she passed about $2 \mathrm{oz}$. of urine of a smoky-brown colour. There was some delirium during the night. At 11 A.M. her pulse was 158 and was better and stronger. Many more petechix were visible; there was no hæmatemesis, epistaxis, or sickness. At 12.45 P.M. she passed $2 \mathrm{o} \%$. of urine of a brown colour together with a dark-red clot of the size of a florin. She slept during the afternoon. At 350 P.M. she passed jus's over $1 \mathrm{oz}$. of urine which was of a paler brown than before. During the night of Sept. 7th-8th she was restless. On Sept. 8th her bowels were not opened and there were no hæmorrhages. She passed urine seven times after 6 P.M. on Sept. 7th of a pale brown colour. She took beef-tea and brandy. Her breatbing was harsh and noisy and her nostrils were blocked with clotted blood. On Sept. 9th and 10th a steam kettle was kept going in the room. There were no more petechiæ or hæmorrhages. The child slept badly and was delirious. Or Sept. 11th urine was passed three or four times into the bed. The child was very restless during the night. More petechiæ appeared; the breathing was still noisy; but she had no cough. On Sept. 12th the bowels were opened twice. The urine was of a pale brown colour. The chila was better; her breathing was better and less noisy. Two or three shirt-button-sized hemorrhagic lumps appeared beneath the skin. During the night of Sept. 12th-13th there was very slight epistaxis, but there was none during the day on Sept. 13th and there were no more spots. The child slept well and her breathing was good, but she took her food badly. On Sept. 14th her left ear discharged pus. On Sept. 15th the urine was more abundant and was of a pale brown colour. Both ears were discharging with some pain in them. Food was taken badly. The bowels were opened three times; there was no blood. On Sept. 18th the child was better and eating better. The aural discharge whs less abundant. There were no fresh spots and the old ones were becoming paler. There were pains in the abdomen but none in the ears. There was no desquamation. On Sept. 20th the urine was quite clear and yellow for the first time. The left ear was still discharging. The spots were fading rapidly and some had gone entirely. The child now made an uneventful recovery, but the petechiæ were not quite gone until Oct. 10th, the day after her third birthday.

The rarity of cases of true purpura hæmorrhagica makes the case interesting. I have purposely abstained from recording it sooner in case there should have been a relapse, for relapses are said to occur frequently. It is now more than two years since the child recovered, but there has been no symptom of recurrence, neither has she had any illness whatever beyond again slight toothache two or three times. The teeth that have ached both before and since the illness have always been the same-riz., the left lower molars. It should be noted that it was on the left side that the rash was most abundant.

The difficulties in the way of treatment of such a case are apparent. The sight of the blood frightened the child; the presence of hæmatemesis interfered with giving medicine by the mouth; the restlessness of the child and her youth prevented any attempts at plugging the nares; and there was, too, the impossibility of persuading the child from pulling the plugs out had they been inserted. The serious condition of the child from loss of blood led to the adoption of injection of ergotin which, if not unique in one so young, must be nearly so; its almost miraculous arrest of the hæmorrhage justified its use. The colour of the rash in true purpura hæmorrhagica is stated to be purple when it first appears and not to become so afterwards. In the above case it seemed to vary in colour with its site, being rose-red where the skin was thin and fine and purple where it was thicker. The petechiæ all went through the colours of a fading bruise.

It is worth noticing that most of the recorded cases of purpura hæmorrhagica occur during the latter months of the year, the majority in September, October, and November, so that the season may prove to be a predisposing cause. Leyton. 